Јемена Ђ. Марићевић ${ }^{1}$

прегледни научни чланак

УДК 821.163.41:821.131.1

DOI 10.21618/srb1702225m

COBISS.RS-ID 7246360

Филозофски факултет у Новом Саду

ОАсек за српску књижевност и језик

\title{
РАСТКО ПЕТРОВИЋ И БЕНВЕНУТО ЧЕЛИНИ: ХЕРМЕНЕУТИЧКИ ИЗАЗОВ 2
}

Апстракт: Рад представља покушај да се одговори на херменеутичко питате зашто јунак романа Буди говоре (1931) чита аутобиограбију италијанског ренесансног златара и вајара Бенвенута Челинија, под насловом Мој живот (итампана 1728) и да ли овај податак има шири семантички значај? Подтекст настанка Челинијевог Живота (он га говори, диктира, тј. не пише га) u поетичка замисао Растка Петровића назначена насловом (Фуди говоре), сугерише пример јединственог надахнућа. Фокус рада је на анализи структуре авангардног романа, која кореспондира са ренесансном алегоријском концепиијом јединог сачуваног Челинијевог дела од драгоценог материјала - златног сланика из 1540. године. Такође, указано је на питате односа између говорета и читата и анализиране су песме „О трену између душе и тела" Растка Петровића и „Разговор између тела и душе” Бенвенута Челинија (итампане у аутобиографији Мој живот), као пример особене инспирисаности ренесансним уметником.

Къучне речи: ренесанса, авангарда, аутобиографија, роман, златарско дело.

\section{УвоА}

Оренесансној вези између Микеланђема (1475-1564) и Мимоша Црњанског (1893-1977), Микеланђемовој меланхолији и сонетима - углавном, о Микеманђему као парадигми уметника, те контекстуанном оквиру Код Хиперборејаща као Микеланђелијане, писано је до сада (уп. Раичевић 2005: 269-383). С Аруге стране, могмо би се поставити питање какав би значај имао Микеманђемов

${ }^{1}$ jelena.maricevic@ff.uns.ac.rs

${ }^{2} \mathrm{PaA} \mathrm{је} \mathrm{настао} \mathrm{при} \mathrm{пројекту} \mathrm{Аспекти} \mathrm{идентитета} \mathrm{и} \mathrm{жихово} \mathrm{обликовағе} \mathrm{у} \mathrm{српској} \mathrm{књижевности}$ (178005), који се реализује на Филозофском факултету у Новом СаАу, а финансиран је од стране Министарства просвете, науке и технолошког развоја Републике Србије. 


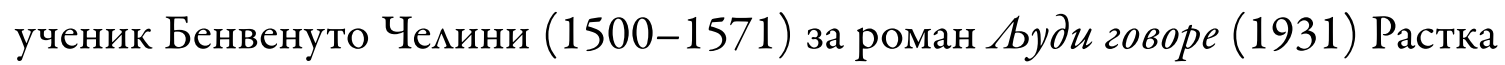
Петровића (1898-1949), те Аа ми се уопште може рећи да је на Растка Петровића италијански вајар и зматар оставио битан поетички траг, као што је то случај са Црњанским и Микеланђелом.

КаАа је реч о учитемско-ученичком односу Микеланђема и Челинија, можАа

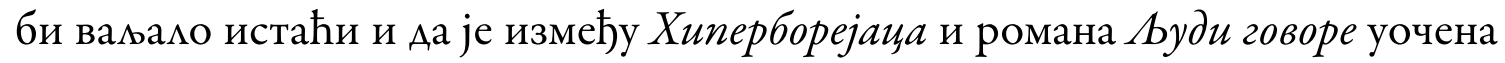
минија додира:

„У књизи 'Код Хиперборејаца' (1966) Мимоша Црњанског, у чијој се сложеној жанровској природи, као и у Растковом деку, укрштају романескно, путописно, аутобиографско, есејистичко и песничко, приповедач који борави у Риму сетиће се у једном тренутку свог пријатеља Растка Петровића: 'Аа бих је развеселио, ја јој обећавам да ћу је водити у ближња места која се зову: Велико и Мало. Maiori - Minori. Чини ми се Аа се налазе у јеАној књизи коју је јеАан наш пријатељ, Растко, у Италији написао"' (Петровић 2006: 86-87).

Предраг Петровић минију додира успоставио је у покушајима Аа се одговори на питање где се нахазе језеро и острва у роману Һуди говоре, износећи и тезе Тодора Манојмовића о иреалној Шпанији, Винаверове о Сицилији и преображавану средине у средину, што је Растку долазимо као рад каквог рецимо ренесансног сликара, запажању о трамонтани као ветру који дува само у Италији, те смештајући роман у временске оквире „оА приближно девет месеци, оА зачећа до рађања новог живота” (уп. Петровић 2006: 86-87). Аутобиографија Бенвенута Челинија унеколико нуди могућност да се сагледа географски простор романа и понуди одговор на смисао ове „топографске мимикрије" (Петровић 2006: 86). Црњански у Хиперборејцима назначава Аа је Растко Петровић књигу написао у Италији, што постаје битан топографски податак, каАа се има у виду потенцијална важност италијанске ренесансе за савремену српску књижевност.

\section{Читање и говор}

Јунак као скушамац и као читалац није ретка појава у књижевности, а његово слушање и читање може Аа буде битно утемељено у семантичку структуру дела. Навели бисмо барем два примера. Познато је да Бокачов Декамерон преАставља оквирну причу о десет младића и девојака који су, скмонивши се оА куге, током десет Аана причали приче. Јунаци нису били читаоци, али су постали приповедачи и скушаоци који се, попут Шехерезаде, налазе преА вра- 
тима смрти. Као репрезентативни пример јунака-читаоца фигурише Евгеније Оњегин: „Оњегин [je] посебно волео два аутора: романтичарског песника Џ. Г. Бајрона и миберацног економисту А. Смита. Татјана се труди да на основу ситних огреботина ноктом и знакова оловком у текстовима сазна 'шта скрива Евгенијева душа”" (Зајац 2015: 200). Татјана није успела да продре у Оњегинову Аушу или је протумачи на основу трагова читања, али се често истиче потреба за идентификацијом са читацачким штивом, што се уклапа у дух оновремене епохе (крај 18. и почетак 19. века): „..бибциотека је постаца израз културне самоидентификације тог доба" (Зајац 2015: 200).

И у српску књижевност, посредством преведене комедије Карла Голдонија Трговци (1753), улази јунак-читалац. КоА Голдонија јунакиња чита часопис Cпектатор, док у преводу Емануила Јанковића јунакиња чита књигу Здрав разум, која насловом кореспондира са просветитеьским идејама 18 . века. ${ }^{3}$ Јунаци-читаоци бими су неретка појава књижевности 18. века, али и књижевности 20. века. У Аругој половини 20. века, нарочито у прози Милорада Павића, тема књижевног јунака као читаоца постаје парадигматична. ${ }^{4}$ Примера раАи, у Последюој вубави у Цариграду Авксентије Папила чита Песму о Еладију (1808) Викентија Ракића, те функција јунака добија следеће именовање: „имагинарни читахац као чувар пишчевог идентитета" (Ераковић 2014: 224). Није искьучена могућност да је Павић био инспирисан фигуром јунака-читаоца код Пушкина, кога је преводио, али и српском књижевношћу 18. и 19. века, па и стварацаштвом Растка Петровића, управо на овом пцану. ${ }^{5}$

Оно што јунак чита, Аакле, углавном је битно функционализовано и у оквирима светске и у оквирима домаће књижевности, што се Аа̂ сагледати из неколико наведених примера. Отуда се може претпоставити Аа и мектира главног јунака романа Һуди говоре није тек произвољно одабрана. Најпре треба рећи да јунак романа Растка Петровића чита Челинијев Живот посве ауго, на путовању и без изгеда да ће завршити читање:

„Седам за сто испод свеће и покушавам да читам Живот Челинијев [...] Живот скулптора Челиниа. Решио сам да је прочитам путујући, и

\footnotetext{
${ }^{3} \mathrm{O}$ разликама између Голдонијеве комедије и Јанковићевог превода/ прераде писао је Ерос Секви (1962: 167-175).

${ }^{4}$ Јован Аелић (1991: 195-258) у књизи о Павићу издвојио је поглавње у коме проблематизује релације аутор - књижевни јунак - читалац у Павићевој прози.

${ }^{5}$ У књизи Авангардни роман без романа ПреАраг Петровић (2008: 223-227) у поглавьу „Енцикмопедијски облик: 'Бурлеска Господина Перуна Бога Грома'” осветлио је роман Растка Петровића у контексту историје нашег романа 20. века (МимораА Павић, Борислав Пекић, Горан Петровић).
} 
Јелена Ђ. Марићевић

тако је читам већ две године, па никад краја. Морам чак да се враћам, јер заборавим шта је бимо. - Како се зове књига? - Живот оА Бенвенута Челиниа. Описан је цео живот Итамије у XVI веку [...] Цео је свет хтео да зна шта читам и да $и$ долазим од Аогорне ими Панкорбе, тј. из Бургоса ими Аериде" (Петровић 2010: 226-227).

Путовања Бенвенута Челинија управо су ишла у смеровима од Италије, преко Француске ка Шпанији, а са̂м уметник нацазио се неретко и у улози ратника. Путања његових кретања можда је и путања којом се креће јунак романа $\not y \partial u$ говоре, те тако читање дуго траје, а јунак се на поједина места враћа у читању, као што се враћа на места која је већ посетио путујући, јер заборавьа шта је бимо, па се тако, након приближно девет месеци, поново вратио на острва и језеро. Са повратком на острво као Аа је завршио поглавье или женски део приче везиье Ивоне, док је у првом делу чуо причу рибара Пипа.

Овакав начин читања, какав практикује јунак романа, можемо одредити као „приватно читање” (Мангел 2005: 161-173), особито ако имамо у виду да су приче Пипа и Ивоне интимне ьубавне приче, које су се скмопиле у његовој слушалачкој свести. Интересантно је Аа сви око јунака желе Аа сазнају шта чита и одакме долази. Он, дакле, није осамьен „у перјаним јастуцима” (Мангел 2005: 161) и не чита ту књигу читаве Аве године зато што је воли и познаје, као типични Мангелови „приватни читаоци”. Радозналост околине можда га омета у концентрисаном читању, а можда у Челинијевом Животу можемо препознати „стварни свет јер је та џиновска књига јеАини извор знања за смртнике" (Мангем 2005: 181), што представља једну оА значајнијих метафора читағь, поред ьудских бића схваћених као књиге, које се могу прочитати. ${ }^{6}$ „За Витмана, текст, аутор, читацац и свет огледају се међусобно у чину читања” (према Мангем 2005: 180), те се стога може рећи да јунак романа Људи говоре и за знатижеьну околину представьа књигу са којом би жемели да се упознају, али то им не успева, као што ни јунаку не успева да упамти Челинијев Живот. Чини се да се између текста, јунака-читаоца и света не успоставьа Аодир, већ се њихов однос своди на пролазну ьубопитьивост код околине и, рекцо би се, симболичку стопьеност јунака с аутобиографијом ренесансног уметника. Није искьучено да је баш то разимажење у разумевању условимо поетичку замисао по којој право разумевање треба тражити у разговору ( а не у читању. 
Аемо Бенвенута Челинија пак, иако настало у 16. веку, штампано је тек 1728. године, заслугом мекара и фимозофа Антонија Кокија, и од тада постаје „симбом ренесансе и узор новог, слободног и суштаственог писања" (Секви 1963: 7). Мој живот штампан је у Напуьу, мада је ставьена ознака да је публикација изашла у Келну, могућно због извесних контроверзних места (оптужби за содомију на пример) (А. В. 1951:378). Растко Петровић боравио је у напуьском крају 1928. године, двеста година након објавьивања Челинијевог Живота, и најпре је написао текст „Напуь - Везув” (1928), Аоцније публикован у књизи Сищилија и други путописи. Тумачење вулкана као симбола одређено је као „везувска астрална евокација” (Аигуори 2015: 107). Растка Петровића импресионирао је контраст у нама, контраст око нас: „Тај контраст ми је давао апсолутнију идеју вредности. Аа сам умео да читам Аантеа некада, читао бих га са таквим осећањем. УпореАо 'Рај' и 'Пакао'” (Петровић 2012: 289-290). На том трагу јесте и укьученост писца и песника у „судар налога биографије и изазова поетике” (Гвозден - ВАадушић 2013: 454).

Цео трећи део романа Һуди говоре јесте у космичким доживьајима, сусрету двеју судбина, живота земье и живота организма, у забкуди ока савршена: „... видим истовремено јеАну звезду која мети изнад мене и јеАну која мети право на мене", у новој муюи, у црној птици која је прхнула у ьуту светлост (уп. Петровић 2010: 251-253). „Ао краја ове ноћи (вечито!) човечанство не постоји. Његова мисао не постоји”, записује Растко Петровић (2010: 252). Аакме, иако у прва Ава поглавња романа писац „еманира широко човекољубње [...] разумевање ьуди и ьудског конституише хумани сегмент у овој прози" (УАовички 1989: $196)^{7}$, у трећем „ми не тражимо ништа Ао Аа будемо заборавьени” (Петровић 2010: 254). Први и Аруги сегмент, који тематизује ьуде, ьубав, патње, судбине, контрастиран је са трећим, космистичким, запитаним наА животом који тек почиње, као јединственим (Петровић 2010: 257).

Укратко, за писца постоји „реалност живота који се интеграцно доживљава чулима, постоји протицање живота који се осећа, постоји мепота живњења али и трагика смрти" (Милијић 1989: 316). Живот који је уметнички осведочен у роману $\measuredangle y \partial и$ говоре декује Аа је контрастиран у односу на Челинијев $M o j$ живот, који прати згоде и незгоде фирентинског уметника од када је као трогодишњак ухватио шкорпију до догађаја из 1562 . године. Челинијева обимна аутобиографија говори најпре о њему и његовој породици, Ааје и пресек живота

\footnotetext{
${ }^{7}$ Винавер је истакао „хуманизам разумевања” у овом роману, Милан Богдановић подвукао је „особену хуманост”, а Миман Аединац демо је именовао као „човечну повест јер ју је писац написао када се зажелео човека" (према УАовички 1989: 196).
} 
Јелена Ђ. Марићевић

човека и уметника ренесансе, интрига и клевета, ратова и хапшења, ами и стварања великих уметничких дела. Најмање је пак у њој речи о суштинској ьубави између човека и жене; Челини чак не помиње свој брак са доном Пијером ди Салваторе, гувернантом којом се оженио и имао више деце (уп. А. В. 1951: 377). Пажьивим читањем Живота вероватно би се могмо констатовати како тешко да постоји ишта што ово дело повезује са романом Растка Петровића.

Ипак, „Чемини је врло мила муда, која пише као да говори”, која постаје „узор снажног, брзог, функционалног причања” (Секви 1963: 12), и он већину своје аутобиографије није написао руком, већ ју је издиктирао: „...чим наиђох на сина Микелеа Аи Горо из Пијеве у области Гротине, четрнаестогодишњег, болешьивог дечака, скмоних га да ме одмени у писању, а ја му казивах у перо све што сам доживео. У томе сам налазио посебно задовољство" (Челини 1963: 18). И коА српског и код италијанског писца имамо, Аакле, опредењење за говор, иако је за Челинија ово опредељење ствар практичности и кичног задовоьства. Челини говори свој Живот, а коА Растка Петровића не говори јунак, већ људи говоре и исповедају му се.

Челинијева проза најслободнија је проза писана у италијанској ренесанси, ослобођена свих терета и окова признатих правила (уп. Секви 1963: 11). На почетку романа Һуди говоре постоји аутопоетички запис о књизи која је значајна по „новости облика, по ономе што садржи” (Петровић 2010: 217). Ренесансна аутобиографија значима је надахнуће и препород за време у коме се појавила у штампаном облику (1728), али представьа симболички препород и новину када је реч о настанку романа из 1931. године, што једним делом и потврђује јунаково читање ренесансне аутобиографије.

\section{Цвет и пчема}

Аруги аутопоетички моменат у роману запретен је у поредбеном исказу између цвета и мектире, писца и пчеле, дела и меда:

„Тако бих волео једном да стварам, скупьајући оно што је најбоље у богатствима око мене, да прерадим то затим у једну хомогеност. На крају раАа пчелиног је мед који садржи у себи срж свих цветова, а није чак ни скуп онога што су они, већ нешто ново и изванреАно. То није ни овај ни онај цвет; то је меА; и особине су толико Арукчије Аа то није ни мирис пре свега, већ укус [...] написати нешто имитујући пчеме, нешто страховито савремено, а што ипак не би бимо: као пчеме” (Петровић 2010: 234). 
Пишући „огмед из компаративне поетике: Сенека, Петрарка, Растко Петровић”, Јован Аелић је наведено аутопоетичко место именовао као „Авангардни ерос ренесансне пчеле", закьучујући:

„Сенека користи поређење умјетника с пчемама да би описао узајамну везу између духовних процеса читања, сакупьања и састављања; дванаест стољећа касније Петрарка исту слику преузима и обогаћује и контексту Аијалога са узорима; шест вјекова послије Петрарке Растко Петровић гради од овог поређења авангардну слику, динамизујући простор и користећи тјелесне и сексуанне метафоре”. Аинамизују се тако и простор и време и традиција (Аелић 2007: 119). ${ }^{8}$

Поред тога што је Фиренца, родно Челинијево место, име добима по цвећу (Челини 1963: 20) и што су Ивону звали и Ролдана (Петровић 2010: 220) Ивона значи тисов шумарак, а Ролдана је жуто цвеће, ако Челинијев Живот схватимо као цвет - Растко Петровић га је читањем обрадио у хомоген меА, у

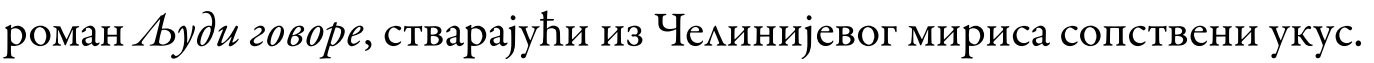

\section{ЗАатарско дело}

Пре него што би направио вајарско или зматарско дело, Бенвенуто Челини би, у скмаду с обичајима заната, најпре сачинио скицу, а затим и модел који се израђивао у пчелињем воску. Тај восак био би пробно дело, прототип за настанак финалног предмета у змату или бронзи. 3Аатни сланик који је Челини за време боравка у Фонтенблу израдио за Франсоу I једино је његово дело у Арагоценом металу које је сачувано до данас.

ГАавна намена овог предмета подстицала је на расправе. Со потиче из мора, а бибер са копна, па је тако део у коме се налазила со обликован у виду мађе коју штити ПосејАон. Бибер је пак у малом славолуку који чува жена што представьа Земьу или можАа Амфитриту. На постову су израђене фигуре које представњају годишња доба и доба Аана. А^егоријско значење ове композиције потврђивало је и Челинијеву импозантну вештину (уп. Јансон 2008: 626-628).

\footnotetext{
${ }^{8}$ Видети и Поетика хуманизма и ренесансе (Пантић 1963: 9-12).
} 
Јелена Ђ. Марићевић

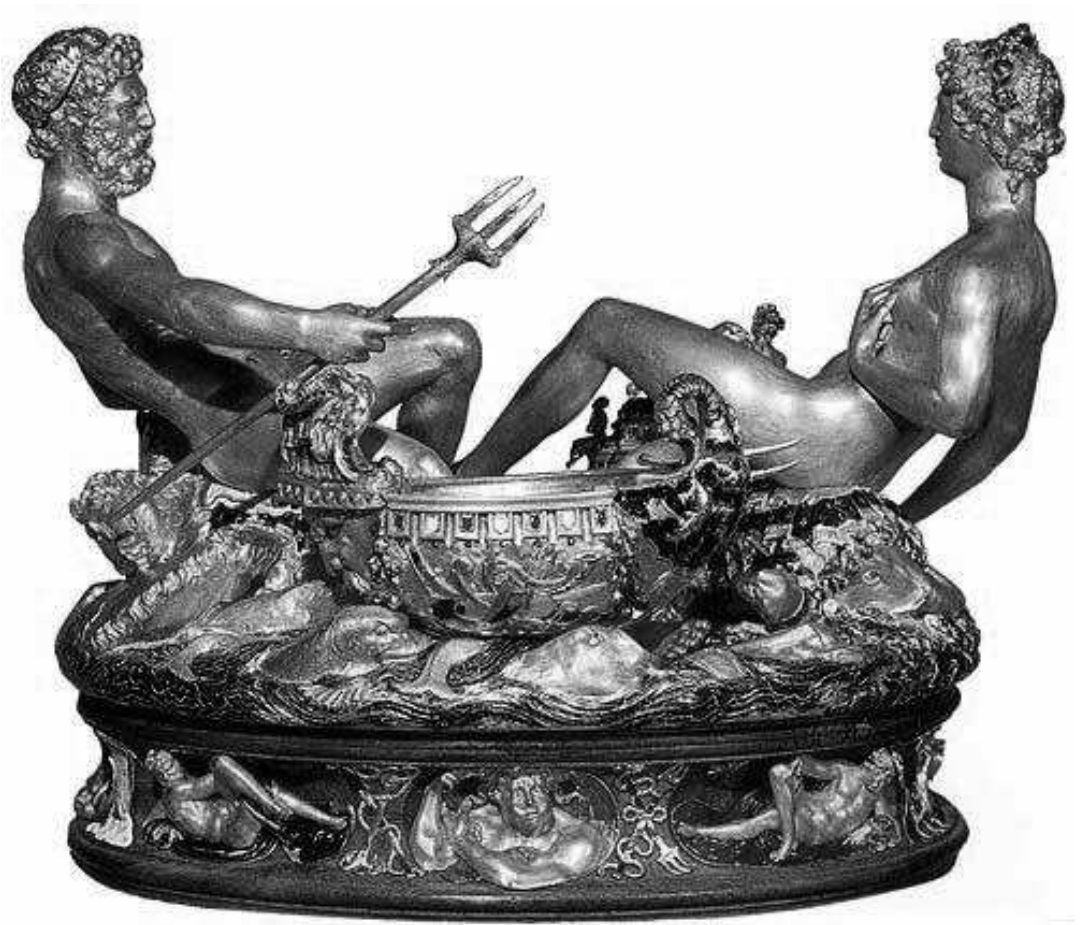

Челинијев зАатни сланик из 1540. године

Ако Растко Петровић и јесте и није стварао попут пчеле, он је без модема у воску, Аиректно у зцату, исписао роман као својеврсно зматарско Аело, које необично мичи на Челинијево, али, за разлику оА њега, Растко Петровић ваја и ствара речима, језиком од змата и драгог камења. Роман је подељен на три Аела (Ава Аијалошка и један монолошки) и на Аневни и ноћни део романа (уп. Петровић 2006). Ако би Пипо на сланику био ПосејАон на мађи, будући Аа је рибар који је барку назвао Ивоном, према имену кћерке и несуђене жене, Ивона би бима жена која представьа Земьу, јер је својим послом везиье и значењем имена везана за посао на копну, а именом за шуму и цвеће. Исповести које говоре јунаку романа функционисаце би као зачини: говор Пипа бима би со романа, а говор Ивоне - бибер. Челинијево постоље са фигурама, које персонификују годишња доба и доба дана, код Растка Петровића икустроване су циклусом оА девет месеци и поделом на дневно и ноћно причање. Скупа узев, творе пејзаж: море (со), земьа (бибер), небо (постоље) ики тоталитет стварности - свет. Ћутање о ьубави Пипа и Ивоне бимо би пакао ове сторије, а рај - њихова исповест, говор, сазнање о ьубави и спознаја тајне. Језеро и острва на којима се све дешава бимо би Средоземно море, које наликује језеру између Европе, Азије и Африке.

Челини је, вајајући скулптуре жена, неретко телесно општио с њима и тај физички контакт у извесном смислу му је омогућавао веран приказ жене у дему 
које ствара: „А мучио сам је и на тај начин што бих је сатима гонио да позира у заморном положају. Колико је то њој било непријатно, толико је мени причињавало задовоьство, јер је она била веома мепо грађена и достојан модел за моја ремек-дема" (Челини 1963: 278). Јунак романа Һуди говоре приближио се са сличном побудом Ивони, али је њу извајао много бцижим контактом. Њена прича Аодирнула му је душу и на тај начин нашиа је одраз у његовом делу:

„Волео сам са усхићењем ту девојку која је трпема у животу, која још трпи и која је дошла да то каже. Заборавио сам зашто сам је звао да дође. $\triangle а$ је то било ради мене а не ради ње. Ја сам егоистички желео да ради Аањег мога живота она унесе у ову ноћ једно осећање среће [...] Волео сам је толико ради 'њене' среће да је и 'моја' почела несвесно да се тиме користи" (Петровић 2010: 249).

\section{Ауша и темо}

Челинијева дела, која је стварао и описивао у аутобиографији, његов су Живот, врло жив, опипьив, телесан, аци не без епифанија и чудесних екстаза које је Аоживьавао: „Ноћу ме у сну походи некакво чудно створење под обцичјем Аивног миадића који ме прекорно упита: 'Знаш ми ти ко ти је подарио то тело, које си хтео пре времена уништити”" (Челини 1963: 208). За стварацаштво Растка Петровића важна је управо фигура млаАића. Аутор есеја симптоматичног наслова „Мцадићство народног генија” остварио је дело саткано оА бурног, Аинамичног, телесног и астралног Живота. Он говори кроз Аикове које ваја и чију Аушу ослушкује.

Обојица уметника имају песму о односу између тема и душе:

Разговор између тела и душе

Жалосна душо, не губи наде,

Разборит човек свцадаће јаде.

Немој ти бити противник Неба,

Оно је извор добра нам свега.

Ко ће нам Аруги помоћи дати, У куку среће ко ће нас звати?
О трену између душе и тела

То није велика шума која шумори, Ни широке пољане које се смеју,

Тиха је река ово између пустих обана!

То није оборени храст што вода носи, То није мртви орао на таласима,

То везани јунак за катарку мотри уморним погледом на све стране. 
Остани, душо, на земьи доле, Видећеш, једном, биће нам боме, Ааће нам Небо мимости своје.

Остаћу јоште некол'ко сати,

Све док наш Творац поглеА не сврати, На синка свога што симно пати.

(Челини 1963: 209)
ПреА њиме, његов га соко разговара:

„Не буди тужан, господару; нисмо ни на небу, ни на земьи.

И пцовићемо Ауго овако, видиш ми!”
И тако увек река носи јеАан меш

И душа би могма, али зар би имаца снаге да га напусти...!

... На високој пманини бор зелен.

То није ни велика шума, ни широка пољана, Ни оборен храст, ни мртви орао;

Соко робује вољно уз везаног господара.

(Петровић 1989: 57)

Бенвенуто Челини није био изванредан песник и, мада је пленио духовитошћу, имагинацијом, одличним зАатарским и вајарским делима, у поезији није ни изблиза био добар као Микеланђело на пример. Постоји могућност да је његова песма, настала у тамници, након сновиђења у којем се јавио ммадић (персонификација његове душе), инспирисала Растка Петровића. Између Чеминијеве и Петровићеве песме, међутим, тешко Аа има кореспонденција вреАних помена, изузев неколико стожерних места. ЈеАно од њих било би мотивско јавьање неба и наглашеност опозиције: горе - доле. Код Растка Петровића соко (који означава Аушу и горњи простор) робује вољно уз свог везаног господара (телесни аспект и Аоњи простор), а живот је налик одисејевској пловидби. Везаност јунака за катарку упућује, наиме, на слику ОАисеја привезаног за катарку брода, који се одупире поју сирена. ОАисеј слуша њихову песму, али га катарке спречавају да га песма одмами у смрт. Јунак из песме Растка Петровића, будући везан за катарку, везан је за живот, а самим тим спојен је са Аушом. Том животу робује јунак (тело), а соко (Ауша) верно робује господару.

КоА Челинија је тело принуђено Аа моли душу да остане на земьи, доле, те нема вољног служења телу - оно је условљено милошћу Творца и угодним животом. Надаље, песничка слика није толико убедьива, нити осенчена митом као код Растка Петровића, што изненађује ако се има у виду изузетна обдареност италијанског уметника, који је и изврсно музицирао у раној животној фази, речју - чији је дух ишао разноликим хоризонтима, који је „страствени 
путник немирна духа" (А. В. 1951: 376), баш као српски писац и песник. ${ }^{9}$ У овој суптилној разлици могао би се наслутити семантички потенцијал односа између Растковог трења и Челинијевог разговора. Између Челинијеве ауше и тела запажа се, наиме, дистанцираност у разговору. ГАас мирског субјекта представља тело, које се обраћа души као детету и теши је причом о бовим временима. Тело делује доминантније у односу на душу, чији се глас чује тек у последњој строфи у којој уцењује тело - остаће „све док наш Творац поглеА не сврати” и која у наслову песме стоји иза речи тело.

С Аруге стране, mреже код Растка Петровића имплицира додир, неминовну слепьеност душе и тела, а искушење смрти у домену је тела јер је тело везано за катарку. Соко (Ауша) може Аа одмети, ами робује верно уз везаног господара и на првом је месту у наслову. Грађена по моделу словенске антитезе, ова песма носи елементе етичности и поетике епског света. И јунак и соко ограничавају своју вољу, не би ми остали заједно/ у зајеАници, тј. у животу. Иако и они разговарају („преА њиме његов га соко разговара”), опредењење за реч трење, којим је илустрован њихов однос, много је Араматичније. Трежем, или робовањем и ограничавањем себе, они се међусобно троше, све док река не однесе један леш.

\section{Закьучак}

Бенвенуто Челини ће „као човјек довијека занимати муде”; био је „човјек који све може, који се све усуђује и своју мјеру носи у самоме себи [...] у том Аику живи узор модерног човјека" (Буркхарт 1989: 222). МожАа је стога Челинија и Растка Петровића повезала сличност животних околности, неприкосновена вера у уметност и раА на том плану, те искуство рата. Иако Челини пише о Аогађајима скоковито, Аинамично и живописно, он ипак не открива своја промишљања о изради својих ремек-дема. Његова аутобиографија „не тежи баш за опажањима вмастите унутрашњости, па ипак описује цјемовитог човјека" (Буркхарт 1989: 222), тј. посредно се конституише представа о њему. Растко Петровић пак, можАа загледан у необичан сланик и биберницу, открива или доживљава причу израђеног дема и то му омогућава да, будући надахнут, то „ново сазнање материјализује и стави у реА проверених искустава, тј. Аа [...] уметнички оствари. Осим тога, подвцачи писац у „Општим подацима и животу песника” (Петровић 2012: 115), „надахнуће тежи још да продужи живот

\footnotetext{
${ }_{9}$ Челини је музицирао за очеву ьубав, а, иначе, уопште није то волео, као што је и Пипо у роману
} 
Јелена Ђ. Марићевић

у правцу тих нових сазнања, која одједном обасјају новим бојама живот и чине се увек као његова права одгонетка".

Роман Һуди говоре могао би да буде одгонетка и одговор на Чеминијев Живот или наставак једног зматарског дела, које, у скмаду са хуманистичким идејама, негује тајну скривене ьубави, подигнуте на пиједестац космичких размера. У судару „нацога биографије и изазова поетике” (Гвозден/ ВАадушић 2013: 454), у питорескним контрастима (бела со: црни бибер $\rightarrow$ човек: жена, Аан: ноћ, живот: смрт), Растко Петровић написао је роман који представља пресек његове епохе, као што то стручњаци кажу за животопис итацијанског зматара: „...отвара нам приступ у свет ренесансе боље него многе академске стуАије и приближава нам тај велики период до те мере Аа нам постаје фамимијаран и близак" (Секви 1963: 14). То је епоха у којој се Медитеран доживьава као језеро, јер су са ренесансом дошла велика географска открића и прекоокеанске пловидбе; то је и експлозија говора, „говорних жанрова, од кратке реплике и Аијалога [...] Ао интимне исповести и поверавања" (према Петровић 2006: 65). У том жамору Растко Петровић доживео је и извајао причу еквивалентну Челинијевом зматарском деку, али у скцаду са сопственом поетиком.

\section{Извори:}

1. Петровић, Растко (1989), Сабране песме, прир. Светлана Веммар Јанковић, БеограА: СКЗ.

2. Петровић, Растко (2010), Ауди говоре, прир. Гојко Тешић: Романи српске авангарде (2), БеограА: Службени гласник - Чигоја.

3. Петровић, Растко (2012), Антологијска едищија: Аесет векова српске къижевности, Растко Петровић, ур. Бојана Стојановић Пантовић, Нови СаА: Матица српска.

4. Челини, Бенвенуто (1963), Мојживот, прев. Југана Стојановић, БеограА: „Бранко Ђоновић”.

\section{Цитирана митература:}

1. A. V. (1951), „Bilješka o piscu”: Benvenuto Cellini, Moj život, prev. Tin Ujević, Zagreb: Matica hrvatska, 375-378.

2. Burckhard, Jacob (1989), Kultura renesanse u Italiji, prev. Milan Prelog, Sremski Karlovci - Novi Sad: Izdavačka knjižarnica Zorana Stojanovića.

3. Гвозден, ВАадимир и Слободан ВАадушић (2013), „Песнички субјект, обогаћивање, путовање: савременост Растка Петровића", Зборник Матиие српске за къижевност и језик, Нови СаА, 61/2, 447-457. 
4. Аелић, Јован (1991), Хазарска призма: тумачене прозе Милорада Павића, БеограА - ТитограА - Горњи Милановац: Просвета - Аосије - Октоих - Аечје новине.

5. Аелић, Јован (2007), „Авангардни ерос ренесансне пчеле; ОглеА из компаративне поетике: Сенека, Петрарка, Растко Петровић”, Упоредна истраживата 4. Српска книжевност између традищионалног и модерног - компаративни аспекти, ур. Бојан Јовић, БеограА: Институт за књижевност и уметност, 113-120.

6. Ераковић, Радослав (2014), „Имагинарни читахац као чувар пишчевог идентитета”, Викентије Ракић, Изабрана дела, прир. Сава Аамјанов и Радослав Ераковић, Нови СаА: Матица српска, 224-228.

7. Зајац, Петер (2015), „Шта је Евгеније Оњегин”, Пулсирағе къижевности, прев. Михах Харпањ, Сремски Карловци - Нови СаА: ИзАавачка књижарница Зорана Стојановића, 191-218.

8. Јансон, Хорст Волдемор (2008), Јансонова историја уметности: западна традиција, прев. Олга Шкарић и Сена Куленовић, БеограА: Моно и Мањана.

9. Liguori, Mario (2015), Vedi Napoli epoi muori: Napulj u srpskim putopisima od 1851. do 1951, Beograd: Službeni glasnik.

10. Мангел, Алберто (2005), Историја читағь, прев. ВАадимир Гвозден, Нови СаА: Светови.

11. Микијић, Бранислава (1989), „Проблеми уметности у естетици Растка Петровића", Книжевно дело Растка Петровића, ур. Ђорђије Вуковић, БеограА: Институт за књижевност и уметност, 299-316.

12. Петровић, Предраг (2006), „Роман приповеда о себи (Дуди говоре Растка Петровића)", Зборник Матице српске за къижевност и језик, Нови СаА, 54/2, 63-88.

13. Петровић, Предраг (2008), Авангардни роман без романа: поетика кратког романа српске авангарде, БеограА: Институт за књижевност и уметност.

14. Раичевић, Горана (2005), Есеји Милоша Црғанског, Сремски Карловци - Нови СаА: Издавачка књижарница Зорана Стојановића.

15. Sekvi, Eros (1962), „I Mercatanti K. Goldonija i prevod E. Jankovića”, Prilozi za knjižeunost, jezik, istoriju i folklor, XXVIII, 3-4, 168-175.

16. Секви, Ерос (1963), „Предговор”: Бенвенуто Челини, Мој живот, прев. Југана Стојановић, БеограА: „Бранко Ђоновић”, 7-14.

17. УАовички, Иванка (1989), „Конституција дела Растка Петровића Ауди говоре”, Книжевно дело Растка Петровића, ур. Ђорђије Вуковић, БеограА: Институт за књижевност и уметност, 191-215. 


\title{
RASTKO PETROVIĆ AND BENVENUTO CELLINI: HERMENEUTICAL CHALLENGE
}

\begin{abstract}
Summary
This paper is an attempt to answer a hermeneutical question: Why does the hero of the novel Ljudi govore (1931) read the autobiography of an Italian Renaissance goldsmith and sculptor, Benvenuto Cellini, entitled My life. Michelangelo is important for the work of Miloš Crnjanski, but it is questionable to which degree his pupil Cellini is important to the work of Rastko Petrović. There is practically no resemblance between the text of the Italian Renaissance biography and the text of the short Serbian avant-garde novel. However, the undertone of the writing of Cellini's Life (he verbalises it, i.e. he does not write it down literally) and the poetical idea of Rastko Petrović emphasised indicated in the title ("People speak"), suggest that we are dealing with a single inspiration. The same conclusion is reached in a short auto poetical excerpt about bees, which affirms its importance (Seneca, Petrarch, Rastko Petrović) in Jovan Delić's paper “The Avant-garde eros of a bee from Renaissance". The paper focuses on the analyses that the conception of an avant-garde novel significantly corresponds to the Renaissance allegorical conception of Cellini's only preserved work made out of a precious material - a golden salt dispenser (including a pepper dispenser) from the year 1540. Rastko Petrovićs novel is presented as a novel made from spoken golden words, as an unusual work of a goldsmith about Man, about love spanning the canvas of the sky, the sea, and earth.
\end{abstract}

